\title{
Niedawne przekształcenia organizacyjno-własnościowe przedsiębiorstw transportu kolejowego w Polsce - część I
}

\author{
Recent organizational and ownership transformation \\ in rail transport companies in Poland - part I
}

\begin{abstract}
ZBIGNIEW TAYLOR, ARIEL CIECHAŃSKI
Instytut Geografii i Przestrzennego Zagospodarowania im. S. Leszczyckiego PAN, 00-818 Warszawa, ul. Twarda 51/55; z.taylor@twarda.pan.pl, ariel@twarda.pan.pl
\end{abstract}

Zarys treści. Celem artykułu jest próba zrekonstruowania przekształceń organizacyjnowłasnościowych przedsiębiorstw transportu kolejowego w Polsce po roku 2000․ Artykuł składa się z dwóch części. W pierwszej, zamieszczonej w niniejszym zeszycie, omawia się zmiany organizacyjne i powstanie nowych przewoźników w transporcie ładunków kolejami normalnotorowymi. Część druga, która ukaże się w Przeglądzie Geograficznym 2011, 83, 2, dotyczy pasażerskich przewoźników kolejami normalnotorowymi i przewoźników w kolejowym transporcie wąskotorowym.

Słowa kluczowe: transformacja systemowa, zmiany organizacyjne, transport kolejowy, przewoźnicy, deregulacja, prywatyzacja, komercjalizacja, geografia przedsiębiorstw.

\section{Wprowadzenie}

Do początku lat 2000. brakowało w Polsce podstaw prawnych zarówno do oddzielenia działalności przewozowej od zarządzania liniami kolejowymi, jak i wykonywania przewozów kolejowych przez inne niż PKP podmioty, a więc do stworzenia elementarnych warunków do powstania konkurencji. Chociaż Ustawa o transporcie kolejowym (1997) miała zliberalizować dostęp do sieci PKP, w praktyce korzystanie z niej przez innych przewoźników było niemożliwe. Ustawa o komercjalizacji, restrukturyzacji $i$ prywatyzacji przedsiębiorstwa państwowego PKP (2000) wprowadziła wymóg posiadania przez zarządców infrastruktury tytułu prawnego do zarządzanych linii kolejowych, w rezultacie czego w 2001 r. skorygowane zostały dotychczas wydane koncesje. Również wyodrębnione w procesie komercjalizacji PKP nowo powstałe spółki Gru-

\footnotetext{
${ }^{1}$ Artykuł powstał częściowo w wyniku realizacji projektu badawczego MNiSW nr N306 024 32/1134.
} 
py - PKP Polskie Linie Kolejowe, PKP Linia Hutnicza Szerokotorowa, PKP Warszawska Kolej Dojazdowa i PKP Szybka Kolej Miejska (w Trójmieście) musiały wystąpić o nowe koncesje na zarządzanie liniami kolejowymi. Jednocześnie wspomniana Ustawa... (2000) wprowadzała wiele ograniczeń (Taylor i Ciechański, 2005).

Dopiero nowa Ustawa o transporcie kolejowym (2003a) dostosowuje polski transport kolejowy do wymogów prawnych i technicznych obowiązujących $\mathrm{w}$ krajach UE. Uprawnienia wynikające $\mathrm{z}$ uprzednio przyznanych koncesji wygasły 29 lutego 2004 r., w związku z tym przedsiębiorstwa prowadzące przewozy kolejowe zobowiązane zostały do wystąpienia do Prezesa Urzędu Transportu Kolejowego, pełniącego rolę regulatora rynku kolejowego, z wnioskiem o udzielenie licencji. Do końca lutego 2004 r. złożono 47 wniosków, z czego 33 przedsiębiorstwa uzyskały licencje (Ocena funkcjonowania..., 2004). Licencja na przewozy potwierdza zdolność przedsiębiorstwa do wykonywania funkcji przewoźnika. W odróżnieniu od dotychczasowych koncesji, licencje wydawane są bez ograniczeń czasoprzestrzennych i przedmiotowych. Podobny zakres mają licencje wydawane przez odpowiednie władze innych państw członkowskich UE.

Równocześnie Ustawa... (2003a) zabrania zarządcy infrastruktury wykonywania przewozów innych niż technologiczne, z jednym wyjątkiem - prowadzenia przewozów osób (pod warunkiem prowadzenia dla tej działalności odrębnej księgowości) lub przewozów osób i towarów na wyodrębnionej organizacyjnie linii (bez odrębnej księgowości, ale pod warunkiem nieudostępniania tej linii innym przewoźnikom). Ustawa znosi też wszelkie formy koncesjonowania działalności polegającej na udostępnianiu linii kolejowych, precyzuje jedynie kim ma być zarządca infrastruktury.

Dopiero wejście w życie Ustawy... (2003a) stworzyło podstawy prawne do pełnej liberalizacji rynku przewozów kolejowych w Polsce. Obecnie, przynajmniej w zakresie przewozów towarowych, działalność może podjąć każdy podmiot, któremu uda się uzyskać licencję. Liczba licencjonowanych przewoźników stale wzrasta (patrz dalej). Pojawiają się także podmioty zainteresowane wykonywaniem przewozów pasażerskich.

Projektowanym aktem prawnym, który będzie regulował sprawy związane z publicznym transportem zbiorowym jest nieuchwalona jeszcze Ustawa o publicznym transporcie zbiorowym (2010). Ma ona określać zasady organizacji i funkcjonowania regularnego przewozu pasażerów w publicznym transporcie zbiorowym. Z drugiej strony ma regulować zasady finansowania regularnych przewozów pasażerskim transportem zbiorowym o charakterze publicznym. To implikuje bardzo istotne z punktu widzenia przewoźników maksymalne okresy trwania umowy na 10 lat w transporcie drogowym oraz 15 lat w transporcie kolejowym, szynowym innym, linowym, linowo-terenowym, morskim 
i śródlądowym ${ }^{2}$. W wielu miejscach zapisy nowego aktu prawnego pokrywają się z zapisami obowiązującej obecnie Ustawy o transporcie drogowym (2001) i wspomnianej już Ustawy o transporcie kolejowym (2003a).

Obecny system prawny z niewielkimi zmianami obowiązuje od $2003 \mathrm{r}$. Mimo to, zmiany organizacyjno-własnościowe $\mathrm{w}$ transporcie kolejowym do połowy lat 2000. były raczej powolne i objęły przede wszystkim niezależnych przewoźników ładunków kolejami normalnotorowymi, natomiast pozostałych przewoźników - w znikomym stopniu (Taylor i Ciechański, 2005; Taylor, 2007). Procesy transformacji nabrały przyspieszenia dopiero w II połowie lat 2000. Właśnie te przekształcenia i ich implikacje są przedmiotem dalszej części artykułu.

\section{Ważniejsze zmiany organizacyjne polskich kolei}

Rok 2000 był ostatnim, w którym PKP funkcjonowały jako przedsiębiorstwo państwowe. Wtedy weszła w życie wspomniana wcześniej Ustawa o restrukturyzacji, komercjalizacji $i$ prywatyzacji przedsiębiorstwa państwowego PKP (2000). Na jej podstawie PP PKP zostało przekształcone w jednoosobową spółkę Skarbu Państwa PKP SA. W 2001 r. z PKP zostały wydzielone 24 spółki, tworzące wraz ze spółką-matką grupę kapitałową (Taylor, 2002; Kierunki..., 2010). Ważniejsze z nich zarządzały infrastrukturą (PKP Polskie Linie Kolejowe), wydzieloną infrastrukturą i przewozami po niej (PKP Linia Hutnicza Szerokotorowa, PKP Warszawska Kolej Dojazdowa, PKP Szybka Kolej Miejska), względnie samymi przewozami (PKP Intercity od 2008 r. spółka akcyjna, PKP Przewozy Regionalne, PKP Cargo). Pozostałe to m.in. zakłady napraw infrastruktury i taboru kolejowego, spółki zajmujące się energetyką, telekomunikacją, informatyką i oddziały gospodarowania nieruchomościami.

Restrukturyzacja PKP objęła również zmiany przyporządkowania taboru kolejowego. Od momentu rozpoczęcia restrukturyzacji w 1997 r. był on najpierw w dyspozycji Dyrekcji Trakcji i Zaplecza Warsztatowego i wraz z nią przeszedł do Dyrekcji Przewozów Towarowych Cargo. Dopiero proces komercjalizacji spowodował zapoczątkowanie przekazywania wagonów pasażerskich i elektrycznych zespołów trakcyjnych do spółek zajmujących się przewozami pasażerskimi. Kolejny etap przekazywania taboru z PKP Cargo miał miejsce dopiero w 2006 r., kiedy to PKP Przewozy Regionalne odkupiły 75 lokomotyw elektrycznych EU07. Ostatecznie w 2008 r. PKP Przewozy Regionalne i PKP Intercity zostały przekazane pozostałe lokomotywy elektryczne i spalinowe, wykorzystywane w ruchu pasażerskim. Pewna liczba lokomotyw spalinowych

\footnotetext{
${ }^{2}$ Wprowadzenie tak długiego okresu trwania umów na pasażerskie przewozy kolejowe postulowane jest od dawna. Dotychczasowe zasady zawierania umów - przede wszystkich rocznych, a najwyżej trzyletnich - wykluczały sensowność wprowadzania nowego taboru (brak gwarancji, że inwestycja zwróci się w przypadku nieprzedłużenia umowy operatorskiej). Poza tym, wiele podmiotów na rynku kolejowym nie było zainteresowanych tak niestabilnymi warunkami funkcjonowania.
} 
przeszła także do PKP Energetyka. Również w 2008 r. w związku z przeprowadzanym usamorządowieniem miały miejsce relokacje taboru - tym razem z PKP Przewozy Regionalne do PKP Intercity przekazany został tabor związany, przynajmniej teoretycznie, z wykonywaniem międzywojewódzkich przewozów pasażerskich.

W transporcie pasażerskim, ważnymi zmianami organizacyjnymi były regionalizacja, a następnie usamorządowienie kolei. Podstawy prawne stworzyła Ustawa ... (2000), powierzająca odpowiedzialność za organizację przewozów regionalnych samorządom wojewódzkim z równoczesnym zagwarantowaniem odpowiednich środków w budżecie państwa. Ustalone zostały nawet konkretne kwoty, które miały być przyznawane w kolejnych latach samorządom na pokrycie deficytu wynikającego z realizacji kolejowych przewozów regionalnych. Wobec faktycznego braku środków na ten cel, samorządy zawierały z przewoźnikiem umowy niegwarantujące efektywnej realizacji przewozów. Potwierdziło to, że finansowanie przewozów regionalnych z budżetu państwa może stanowić zagrożenie dla ich należytego wykonywania. Dopiero Ustawa o dochodach jednostek samorzadu (2003b) wprowadziła znaczące zmiany w zasadach organizacji i finansowania kolejowych przewozów regionalnych. Odtąd całkowitą odpowiedzialność za organizację i dotowanie przewozów (jako służby publicznej) oraz nabywanie pojazdów szynowych ponoszą samorządy wojewódzkie; przewozy regionalne stały się ich zadaniem własnym. To rozwiązanie spowodowało znaczący przyrost środków na dotacje w ostatnich latach (Dyr, 2008).

Istotną zmianą o charakterze organizacyjnym było usamorządowienie PKP Przewozy Regionalne, które miało miejsce w grudniu 2008 r. Proces ten poprzedziły wielomiesięczne przygotowania, w tym również mające na celu zapewnienie przewoźnikom stabilnej sytuacji ekonomicznej (oddłużenie, zapewnienie środków na działalność). Służyła temu nowelizacja Ustawy o komercjalizacji, restrukturyzacji i prywatyzacji z 2000 r. (Ustawa..., 2008), która wskazywała źródła środków na oddłużenie PKP Przewozy Regionalne i zasady przeprowadzenia usamorządowienia. W ramach przygotowań do przekazania spółki wydzielono w niej Oddział Przewozów Międzywojewódzkich (OPM), obsługujący pociągi pospieszne - założeniem wdrażanej reformy było bowiem przekazanie samorządom wyłącznie najmniej rentownych pociągów osobowych. Pod koniec 2008 r. OPM został przejęty wraz z częścią taboru i pracowników przez spółkę PKP Intercity, zaś udziały PKP Przewozy Regionalne zostały przekazane wszystkim 16 województwom, zgodnie ze specjalnym Rozporzadzeniem (Rozporzadzenie..., 2008).

O wielkości udziałów poszczególnych województw decydowały cztery kryteria: (1) wielkość województwa, (2) liczba ludności, (3) długość linii kolejowych eksploatowanych w danym województwie, oraz (4) średnia wielkość pracy eksploatacyjnej wykonywanej w ostatnich trzech latach (Rozporzaddzenie..., 2008). 
Tabela 1. Struktura własnościowa PKP Przewozy Regionalne w momencie usamorządowienia (według liczby udziałów i udziału procentowego)

Ownership structure of the PKP Przewozy Regionalne company at the moment of self-governing (by numbers of shares and percentage share)

\begin{tabular}{|l|c|c|}
\hline \multicolumn{1}{|c|}{$\begin{array}{c}\text { Województwo } \\
\text { Voivodship }\end{array}$} & $\begin{array}{c}\text { Liczba udziałów } \\
\text { Number of shares }\end{array}$ & $\begin{array}{c}\text { Udział (\%) } \\
\text { Percentage }\end{array}$ \\
\hline Dolnośląskie & 92750 & 7,3 \\
Kujawsko-pomorskie & 73691 & 5,8 \\
Lubelskie & 69880 & 5,5 \\
Lubuskie & 45739 & 3,6 \\
Eódzkie & 72421 & 5,7 \\
Małopolskie & 81315 & 6,4 \\
Mazowieckie & 171523 & 13,5 \\
Opolskie & 43198 & 3,4 \\
Podkarpackie & 62257 & 4,9 \\
Podlaskie & 48281 & 3,8 \\
Pomorskie & 90208 & 7,1 \\
Śląskie & 116890 & 9,2 \\
Świętokrzyskie & 38116 & 3,0 \\
Warmińsko-mazurskie & 67339 & 5,3 \\
Wielkopolskie & 123243 & 9,7 \\
Zachodniopomorskie & 73691 & 5,8 \\
Opracowanie własne na podstawie: Rozporzadzenie... (2008). \\
Authors' own compilation based on: Rozporzqdzenie... (2008).
\end{tabular}

Sytuacja przedstawiona w tabeli 1 wymaga komentarza. Zadziwiający jest szczególnie wysoki udział województwa mazowieckiego dysponującego już własną spółką (Koleje Mazowieckie), a co ważniejsze - na terenie którego nie odbywał się ruch pociągów PKP Przewozy Regionalne w ramach służby publicznej. Sytuacja jest więc kuriozalna i władze samorządowe województwa sygnalizowały kilkakrotnie chęć pozbycia się swoich udziałów. Szybko okazało się jednak, że PKP Przewozy Regionalne (obecnie pod nazwą Przewozy Regionalne) są firmą w słabej kondycji ekonomicznej, co zaowocowało znacznymi kłopotami z regulowaniem bieżących zobowiązań wiosną 2010 r. Generalnie, zniechęcone wciąż rosnącymi kosztami samorządy szukają ratunku w tworzeniu własnych spółek z wykorzystaniem posiadanego taboru. Obecnie najbardziej zaawansowane są prace w przypadku województwa wielkopolskiego (Koleje Wielkopolskie) i śląskiego (Koleje Śląskie). 
Warto wspomnieć jeszcze o dwóch zagadnieniach związanych z restrukturyzacją PKP. Pierwszym jest konsolidacja zakładów napraw infrastruktury. W 2007 r. przedsiębiorstwo w Katowicach oraz zakłady w Radomiu, Stargardzie Szczecińskim i Warszawie zostały połączone w jedno przedsiębiorstwo z siedzibą w Warszawie, zaś dotychczasowe spółki stały się zakładami nowego podmiotu. W ramach dalszych działań restrukturyzacyjnych część udziałów zarówno tej spółki, jak i pozostałych dawnych zakładów, została przekazana na rzecz PKP Polskie Linie Kolejowe.

Ciekawe są również procesy zachodzące w spółce PKP Cargo. Z jednej strony odbywa się konsolidacja zakładów spółki, w wyniku której zamiast dotychczasowych zakładów taboru i zakładów przewozów towarowych powstały spółki zlokalizowane w 16 miejscowościach. Jednocześnie postępuje wyłączanie działalności naprawczej poza główną spółkę. Odbywa się to w postaci tworzenia od 2005 r. jednoosobowych spółek PKP Cargo Wagon na bazie sekcji napraw wagonów w Toruniu, Krakowie, Jaworzynie Śląskiej, Tarnowskich Górach i Szczecinie. W Czerwieńsku, Ostrowie Wielkopolskim i Zduńskiej Woli Karsznicach powstały spółki PKP Cargo Tabor zajmujące się naprawami wagonów i lokomotyw. W 2010 r. spółka PKP Cargo Wagon w Toruniu podjęła także naprawy taboru trakcyjnego. Obecnie, w przededniu prywatyzacji PKP Cargo, rozważane jest przekazanie na jej rzecz części udziałów PKP Linia Hutnicza Szerokotorowa.

Ustawa o transporcie kolejowym (1997) sprawiła, że oprócz PKP swoje sieci kolejowe zaczęły udostępniać przewoźnikom także inne podmioty. Ponadto, restrukturyzacja PKP spowodowała, że w wyniku podziału tego przedsiębiorstwa powstało czterech odrębnych zarządców infrastruktury kolejowej (tab. 2). Jednak najwięcej nowych niezależnych podmiotów powstało na Górnym Śląsku. Wynikało to z istnienia dobrze rozwiniętej, niezależnej infrastruktury kolejowej powiązanej z górnictwem piasku posadzkowego i węgla kamiennego - stąd zarządcami stały się wszystkie cztery kopalnie piasku ${ }^{3}$, Przedsiębiorstwo Transportu Kolejowego i Gospodarki Kamieniem w Rybniku oraz specjalnie powołana do tego celu - Jastrzębska Spółka Kolejowa (tab. 2).

\footnotetext{
${ }^{3}$ W 1990 r. z Przedsiębiorstwa Materiałów Podsadzkowych Przemysłu Węglowego zostały wydzielone (oprócz firm zaplecza technicznego) cztery samodzielne kopalnie piasku utworzone z dotychczasowych zakładów wydobywczych: Kuźnica Warężyńska w Dąbrowie Górniczej, Szczakowa w Jaworznie, Kotlarnia w Kotlarni i Maczki Bór w Sosnowcu. Początkowo wspomniane kopalnie otrzymały status przedsiębiorstw państwowych. W 1994 r. kopalnię Kuźnica Warężyńska przekształcono w jednoosobową spółkę Skarbu Państwa, a rok później wniesiono jej udziały do NFI. Identycznie wyglądała sytuacja w przypadku kopalni Szczakowa i Kotlarnia. Kopalnia Maczki Bór w latach 1992-2001 pozostawała jednoosobową spółką Skarbu Państwa (Ciechański, 2002). W 2001 r. zapoczątkowane zostały procesy prywatyzacji - udziałowcem Kopalni Piasku Maczki Bór stała się spółka z obecnej Grupy CTL Logistics. Dwa lata później, w ręce niemieckiej firmy PCC przeszła Kopalnia Piasku Szczakowa. W podobnym okresie PTKiGK Zabrze stało się właścicielem Kopalni Piasku Kuźnica Warężyńska. Niezależnym przedsiębiorstwem pozostaje (2010) jedynie Kopalnia Piasku Kotlarnia. W rezultacie ustawowego wymogu oddzielenia działalności przewozowej od zarządzania infrastrukturą w dotychczasowych trzech kopalniach (oprócz Kuźnicy Warężyńskiej) wydzielono odrębne podmioty zajmujące się zarządzaniem posiadanymi sieciami kolejowymi.
} 
Tabela 2. Skrócona charakterystyka sieci poszczególnych zarządów kolei w Polsce w $2001 \mathrm{r}$. Brief characterisation of networks belonging to different rail boards in Poland, 2001

\begin{tabular}{|c|c|c|}
\hline & $\begin{array}{c}\text { Zarząd kolei } \\
\text { Rail board }\end{array}$ & $\begin{array}{c}\text { Długość sieci } \\
\text { Length of network } \\
(\mathrm{km})\end{array}$ \\
\hline \multirow{4}{*}{ 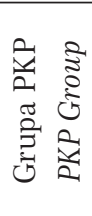 } & PKP PLK SA & 19668,1 \\
\hline & PKP LHS sp. z o.o. & 394,6 \\
\hline & PKP WKD sp. z o.o. & 38,8 \\
\hline & PKP SKM w Trójmieście sp. z o.o. & 32,4 \\
\hline \multirow{6}{*}{ 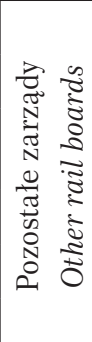 } & Kopalnia Piasku Kotlarnia SA w Kotlarni & 109,2 \\
\hline & Kopalnia Piasku Maczki Bór sp. z o.o. w Sosnowcu & 53,7 \\
\hline & $\begin{array}{l}\text { Przedsiębiorstwo Transportu Kolejowego i Gospodarki Kamieniem } \\
\text { SA w Rybniku }\end{array}$ & 43,5 \\
\hline & Kopalnia Piasku Szczakowa SA w Jaworznie & 41,6 \\
\hline & Jastrzębska Spółka Kolejowa sp. z o.o. & 26,7 \\
\hline & Kopalnia Piasku Kuźnica Warężyńska SA w Dąbrowie Górniczej & 20,5 \\
\hline
\end{tabular}

Opracowanie własne na podstawie: Raport 2001 (2002); Ciechański (2003); www.lhs.pl; Wykaz linii... D29 (1999).

Authors' own compilation based on: Raport 2001 (2002); Ciechański (2003); www.lhs.pl; Wykaz linii... D29 (1999).

W 2010 r. spośród zarządców infrastruktury wywodzących się z Grupy PKP funkcjonujących w 2001 r., usługi udostępniania linii kolejowych świadczyły tylko PKP PLK i PKP SKM. Dwie pozostałe - PKP LHS i PKP WKD - wykorzystywały infrastrukturę kolejową wyłącznie do realizacji własnych przewozów. Także wśród niezależnych zarządców infrastruktury doszło do dość radykalnych zmian. Sieć kolejowa Kopalni Piasku Kuźnica Warężyńska utraciła status linii kolejowych i zaczęto ją traktować jako bocznice. Sieci kolejowe zarządzane przez PTKiGK Rybnik i Śląskie Linie Kolejowe (Grupa PCC Rail) oraz niektóre odcinki w zarządzie PTK Holding z Zabrza w wyniku zakupu PCC Rail i PTKH zostały połączone w jedną firmę DB Infrastruktura, obecnie funkcjonującą pod nazwą Infra Silesia. Pojawiły się także dwa zupełnie nowe podmioty. Należąca do Jastrzębskiej Spółki Węglowej kopalnia Budryk zarządza 9,3-kilometrową linią kolejową łączącą ją ze stacją PKP PLK w Knurowie, natomiast UBB Polska zarządza zaledwie 1,5-kilometrowym odcinkiem granica państwa-Świnoujście Centrum (tab. 3). 
Tabela 3 . Skrócona charakterystyka sieci poszczególnych zarządów kolei w Polsce w 2010 r.

Brief characterisation of networks belonging to different rail boards in Poland, 2010

\begin{tabular}{|c|l|c|}
\hline & \multicolumn{1}{|c|}{$\begin{array}{c}\text { Zarząd kolei } \\
\text { Rail board }\end{array}$} & $\begin{array}{c}\text { Długość sieci } \\
\text { Length of network } \\
(\mathrm{km})\end{array}$ \\
\hline \multirow{2}{*}{$\begin{array}{c}\text { Grupa PKP } \\
\text { PKP Group }\end{array}$} & PKP PLK SA & 19336,0 \\
\hline \multirow{3}{*}{$\begin{array}{c}\text { Pozostałe zarządy SKM w Trójmieście sp. z o.o. } \\
\text { Other rail boards }\end{array}$} & Kopalnia Piasku Kotlarnia Linie Kolejowe sp. z o.o. & 32,4 \\
& Infra Silesia SA & 121,5 \\
& Jastrzębska Spółka Kolejowa sp. z. o.o. & 98,0 \\
& Jastrzębska Spółka Węglowa SA KWK Budryk & 47,3 \\
& UBB Polska sp. z o.o. w Świnoujściu & 29,9 \\
\hline
\end{tabular}

Opracowanie własne na podstawie: www.plk-sa.pl; www.lhs.pl; Ciechański (2003); Regulaminy przydzielania i korzystania z tras - Kopalnia Piasku Kotlarnia-Linie Kolejowe, Infra Silesia, Jastrzębska Spółka Kolejowa, KWK Budryk i CTL Maczki Bór.

Authors' own compilation based on the above sources.

\section{Niezależni przewoźnicy ladunków na kolejach normalnotorowych}

Do początku 2002 r. linie PKP PLK były dostępne dla przewoźników niezależnych, pochodzących spoza Grupy PKP SA, w bardzo ograniczonym stopniu. Większość operatorów wykonywała przewozy po torach należących do śląskich zarządów dawnych kolei przemysłowych. Jednakże, sieć kolei przemysłowych była zdecydowanie za mała do rozwoju firm przewozowych, zwłaszcza że wskutek restrukturyzacji górnictwa ubywało kopalń węgla kamiennego będących odbiorcą piasku podsadzkowego i dostawcą wydobytego węgla do odbiorców. Przewoźnicy skupili się, za pośrednictwem sieci kolei piaskowych, na obsłudze energetyki, mającej niedobre doświadczenia ze współpracy z PKP. Wiele elektrowni i elektrociepłowni przestawiło się na całkowitą lub dominującą obsługę przez przewoźników spoza Grupy PKP SA. Na przykład, kopalnia piasku Kuźnica Warężyńska stała się głównym dostawcą węgla do elektrowni Łagisza w Będzinie, kopalnia piasku Szczakowa - do elektrowni Jaworzno II i Jaworzno III. Obsługę elektrowni Rybnik przejęły kopalnia piasku Kotlarnia i PTKiGK Rybnik, a elektrociepłowni Zabrze i Tychy - PTKiGK Zabrze (Ciechański, 2002).

W wyniku realizacji procesu licencyjnego do połowy 2005 r. pojawiło się ponad 15 nowych przewoźników. Jednocześnie 11 dotychczasowych koncesjonariuszy nie wystąpiło o licencje. Część z nich przeniosła działalność do odręb- 
nych przedsiębiorstw transportowych, które brały udział w późniejszych postępowaniach licencyjnych. Także wśród nowych licencjobiorców są spółki zależne od dotychczasowych uczestników procesu licencyjnego.

Ogółem do końca sierpnia 2010 r. wydano licencje na przewozy towarowe kolejami 88 podmiotom (tab. 4). Szczytowy okres procesu licencyjnego przypadł na lata 2003-2005, kiedy to wydawano rocznie od 14 do 25 licencji dla nowych operatorów. W kolejnych latach tempo przyrostu liczby nowych przewoźników towarowych znacząco spadło, do 5-7 podmiotów rocznie (ryc. 1). Faktyczna liczba udzielanych licencji była jednak większa - obejmowała ona zarówno zmiany licencji wynikające ze zmian nazw firm czy też wydawanie nowych dokumentów, jeżeli ważność dotychczasowych skończyła się. W większości przypadków jednak utrata licencji była ostateczna - tak z polskiego ryn-

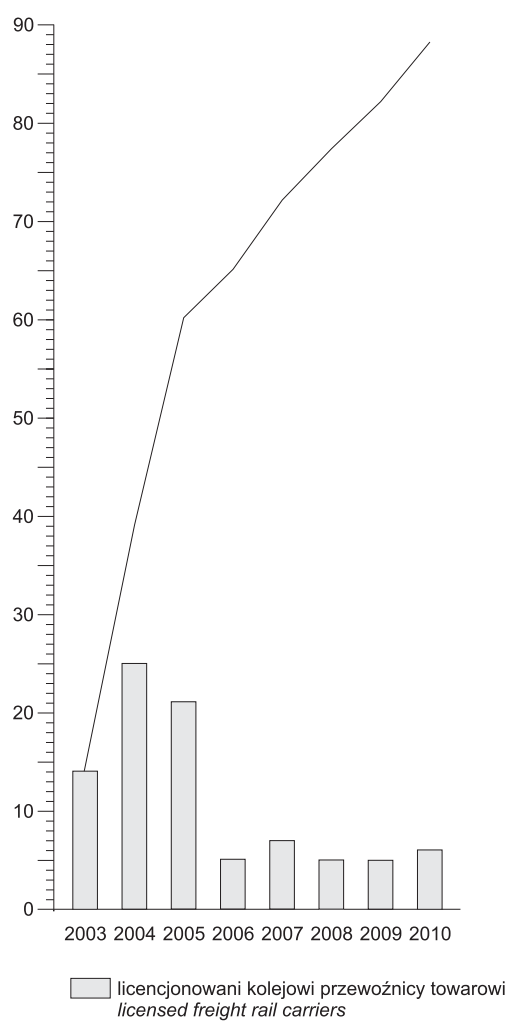

Ryc. 1. Licencjonowani kolejowi przewoźnicy towarowi w latach 2003-2010. Słupki przedstawiają liczbę nowych przewoźników w danym roku, a krzywa skumulowaną ich liczbę. Opracowanie własne.

Licensed rail freight carriers, 2003-2010. Bars denote the number of new carriers in a given year, while the line shows the cumulative number of new carriers.

Authors' own work. 
Tabela 4. Licencjonowani przewoźnicy towarowi kolejami normalno- i szerokotorowymi w Polsce (stan na sierpień 2010 r.)

Licensed freight carriers on standard- and broad-gauge railways in Poland (as of August 2010)

\begin{tabular}{|c|c|c|}
\hline $\begin{array}{l}\text { Aktualna nazwa podmiotu } \\
\text { Present name of carrier }\end{array}$ & $\begin{array}{c}\text { Data } \\
\text { uzyskania } \\
\text { Licence } \\
\text { granted on }\end{array}$ & $\begin{array}{c}\text { Data } \\
\text { cofnięcia } \\
\text { Licence } \\
\text { withdrawn } \\
\text { on } \\
\end{array}$ \\
\hline Pol-Miedź Trans sp. z o.o. w Lubinie & 29.08 .2003 & \\
\hline $\begin{array}{l}\text { Przedsiębiorstwo Produkcyjno-Handlowo-Usługowe Kolex } \\
\text { sp. z o.o. we Włosienicy koło Oświęcimia }{ }^{\mathrm{a}}\end{array}$ & 29.08.2003 & 13.02 .2009 \\
\hline $\begin{array}{l}\text { Przedsiębiorstwo Transportowe Zespołu Elektrociepłowni } \\
\text { Wrocław ZEC-Trans sp. z o.o. we Wrocławiu }\end{array}$ & 29.08.2003 & 13.02 .2009 \\
\hline CTL Logistics sp. z o.o. & 30.08 .2003 & \\
\hline Lotos Kolej sp. z o.o. w Gdańsku & 08.10 .2003 & \\
\hline Nadwiślański Zakład Transportu Kolejowego sp. z o.o. w Woli & 08.10 .2003 & \\
\hline Transoda sp. z o.o. w Inowrocławiu & 08.10 .2003 & \\
\hline PKP Cargo SA w Warszawie & 24.11 .2003 & \\
\hline DB Schenker Rail Polska SA & 28.11.2003 & \\
\hline DB Schenker Rail Rybnik SA & 28.11.2003 & \\
\hline DB Schenker Rail SA & 28.11.2003 & \\
\hline DB Schenker Rail Spedkol sp. z o.o. & 28.11.2003 & \\
\hline DB Schenker Rail Coaltran sp. z o.o. & 28.11.2003 & \\
\hline Kopalnia Piasku Kotlarnia SA w Kotlarni & 28.11.2003 & \\
\hline CTL Maczki Bór sp. z o.o. w Sosnowcu & 12.01.2004 & \\
\hline Południowy Koncern Węglowy SA & 12.01.2004 & \\
\hline Euronaft Trzebinia sp. z o.o. w Trzebini & 12.01.2004 & \\
\hline Polski Koncern Naftowy Orlen SA w Płocku & 12.01 .2004 & 28.08 .2009 \\
\hline Zakład Inżynierii Kolejowej sj. w Sandomierzu & 12.01 .2004 & \\
\hline Tankpol sp. z o.o. w Szczucinie & 12.01 .2004 & 26.03.2007 \\
\hline Kopalnia Piasku Kuźnica Warężyńska SA w Dąbrowie Górniczej & 10.02 .2004 & 22.06.2007 \\
\hline PKP Linia Hutnicza Szerokotorowa sp. z o.o. w Zamościu & 27.02 .2004 & \\
\hline PKP Intercity SA & 27.02 .2004 & \\
\hline Przewozy Regionalne sp. z o.o. & 27.02.2004 & \\
\hline Warszawska Kolej Dojazdowa sp. z o.o. & 27.02 .2004 & \\
\hline Orlen KolTrans sp. z o.o. w Płocku & 27.02 .2004 & \\
\hline $\begin{array}{l}\text { Przedsiębiorstwo Usług Kolejowych Kolprem sp. z o.o. } \\
\text { w Dąbrowie Górniczej }\end{array}$ & 27.02 .2004 & \\
\hline $\begin{array}{l}\text { Przedsiębiorstwo Robót Kolejowych i Inżynieryjnych SA } \\
\text { we Wrocławiu }\end{array}$ & 27.02 .2004 & \\
\hline Kolej Bałtycka SA w Szczecinie & 27.02 .2004 & \\
\hline Kolhut sp. z o.o. w Krakowie & 27.02 .2004 & 21.08 .2008 \\
\hline CTL Rail sp. z o.o. w Katowicach & 02.03 .2004 & \\
\hline
\end{tabular}




\begin{tabular}{|c|c|c|}
\hline $\begin{array}{l}\text { Aktualna nazwa podmiotu } \\
\text { Present name of carrier }\end{array}$ & $\begin{array}{l}\text { Data } \\
\text { uzyskania } \\
\text { Licence } \\
\text { granted on }\end{array}$ & $\begin{array}{c}\text { Data } \\
\text { cofnięcia } \\
\text { Licence } \\
\text { withdrawn } \\
\text { on } \\
\end{array}$ \\
\hline Lubelski Węgiel Bogdanka SA w Puchaczowie & 05.03.2004 & \\
\hline GATX Rail Poland sp. z o.o. w Warszawie & 30.03.2004 & \\
\hline Przedsiębiorstwo Robót Kolejowych SA w Krakowie & 30.03.2004 & \\
\hline $\begin{array}{l}\text { Przedsiębiorstwo Kompleksowej Obsługi Bocznic Kolejowych } \\
\text { Petekol sp. z o.o. w Zabrzu }\end{array}$ & 22.04.2004 & 18.06.2006 \\
\hline DB Schenker Rail Kolchem sp. z o.o. & 29.04.2004 & \\
\hline $\begin{array}{l}\text { Przedsiębiorstwo Komunikacji Samochodowej Zielona Góra } \\
\text { sp. z o.o. w Zielonej Górze }\end{array}$ & 20.10.2004 & 21.12.2006 \\
\hline Rail Polska sp. z o.o. w Warszawie & 20.10 .2004 & \\
\hline RCO SA & 23.12.2004 & 10.11.2009 \\
\hline Koleje Mazowieckie sp. z o.o. w Warszawie & 28.12.2004 & \\
\hline CTL Train sp. z o.o. w Warszawie & 24.01.2005 & \\
\hline GreenChip Cargo sp. z o.o. & 14.02.2005 & \\
\hline Przedsiębiorstwo Transportu Kolejowego Koltar sp. z o.o. & 08.03.2005 & \\
\hline Torpol sp. z o.o. w Poznaniu & 08.03.2005 & \\
\hline Polski Tabor sp. z o.o. w Warszawie & 08.03.2005 & 21.07.2006 \\
\hline X Train sp. z o.o. w Warszawie & 09.05.2005 & \\
\hline Zakład Napraw Infrastruktury Radom sp. z o.o. w Radomiu & 09.05.2005 & 20.11.2007 \\
\hline STK SA & 17.05.2005 & \\
\hline Pomorskie Przedsiębiorstwo Mechaniczno-Torowe sp. z o.o. & 17.05.2005 & \\
\hline Szybka Kolej Miejska w Warszawie sp. z o.o. & 08.06.2005 & \\
\hline PPH Kolinstal Henryk Jakubiec & 21.06.2005 & \\
\hline $\begin{array}{l}\text { Dolnośląskie Przedsiębiorstwo Napraw Infrastruktury } \\
\text { Komunikacyjnej Dolkom sp. z o.o. }\end{array}$ & 25.07.2005 & \\
\hline CTL Lok sp. z o.o. & 18.08.2005 & \\
\hline Przedsiębiorstwo Napraw Infrastruktury sp. z o.o. & 29.08 .2005 & \\
\hline Antra sp. z o.o. & 19.09.2005 & 02.11 .2006 \\
\hline $\begin{array}{l}\text { Przedsiębiorstwo Utrzymania Infrastruktury Kolejowej } \\
\text { w Katowicach sp. z o.o. }\end{array}$ & 27.09.2005 & 02.11 .2006 \\
\hline CTL Express sp. z o.o. & 10.11 .2005 & \\
\hline CTL Regio sp. z o.o. & 10.11 .2005 & 21.09.2007 \\
\hline Freightliner PL sp. z o.o. & 07.12 .2005 & \\
\hline Majkoltrans sp. z o.o. & 13.12.2005 & \\
\hline Cemet SA & 30.05.2006 & \\
\hline FHU Orion Kolej Krzysztof Warchoł & 06.07.2006 & \\
\hline CTL Kolzap sp. z o.o. & $\begin{array}{l}06.07 .2006 \\
25.08 .2009\end{array}$ & 21.09.2007 \\
\hline CTL Tankpol sp. z o.o. & 12.12.2006 & \\
\hline
\end{tabular}




\begin{tabular}{|c|c|c|}
\hline $\begin{array}{l}\text { Aktualna nazwa podmiotu } \\
\text { Present name of carrier }\end{array}$ & $\begin{array}{c}\text { Data } \\
\text { uzyskania } \\
\text { Licence } \\
\text { granted on }\end{array}$ & $\begin{array}{c}\text { Data } \\
\text { cofnięcia } \\
\text { Licence } \\
\text { withdrawn } \\
\text { on } \\
\end{array}$ \\
\hline Hagans Logistic sp. z o.o. & 12.12.2006 & \\
\hline Polzug Intermodal Polska sp. z o.o. & 16.02 .2007 & \\
\hline Loreco sp. z o.o. & 23.04 .2007 & \\
\hline Newag SA & 29.05.2007 & \\
\hline Transchem sp. z o.o. & 26.06.2007 & \\
\hline PKP Energetyka SA & 04.07.2007 & \\
\hline CTL Kargo sp. z o.o. & 30.10 .2007 & \\
\hline ITL Polska sp. z o.o. & 10.12.2007 & \\
\hline East West Railways sp. z o.o. & 05.05 .2008 & \\
\hline Zakład Robót Komunikacyjnych - DOM w Poznaniu sp. z o.o. & 05.05 .2008 & \\
\hline Zakłady Naprawcze Lokomotyw Elektrycznych SA & 05.05.2008 & \\
\hline CTL Trans-Port sp. z o.o. & 30.07 .2008 & \\
\hline $\begin{array}{l}\text { Przedsiębiorstwo Napraw i Utrzymania Infrastruktury Kolejowej } \\
\text { w Krakowie sp. z o.o. }\end{array}$ & 21.08 .2008 & \\
\hline $\begin{array}{l}\text { Zakłady Produkcyjno Naprawcze Maszyn i Urządzeń Tabor } \\
\text { M. Dybowski sj. }\end{array}$ & 26.05.2009 & \\
\hline Philip sp. z o.o. & 08.06.2009 & \\
\hline Tabor Szynowy Opole SA & 07.08.2009 & \\
\hline Koleje Czeskie sp. z o.o. & 28.08.2009 & \\
\hline Dolnośląskie Linie Autobusowe sp. z o.o. & 09.11 .2009 & \\
\hline Zakład Przewozów i Spedycji Spedkoks sp. z o.o. & 12.01.2010 & \\
\hline Wiskol Sołtys Waldemar, Sołtys Jarosław sj. & 18.01.2010 & \\
\hline S\&K Train Transport sp. z o.o. & 08.02 .2010 & \\
\hline PHU Lokomotiv Bronisław Plata & 30.04 .2010 & \\
\hline ExTRail sp. z o.o. & 04.05 .2010 & \\
\hline Bartex sp. z o.o. & 19.08 .2010 & \\
\hline
\end{tabular}

${ }^{\mathrm{a}}$ zakupione przez Rail Polska / bought by Rail Polska.

Opracowanie własne na podstawie: Koncesje i licencje... (2003); www.utk.gov.pl. Authors' own compilation based on: Koncesje i licencje... (2003); www.utk.gov.pl.

ku przewozów kolejowych zniknęły m.in. firmy Tankpol ze Szczucina, Kolhut z Krakowa, PKS Zielona Góra, RCO SA czy Antra. Inne traciły licencje łącząc się z podobnymi podmiotami - głównie chodzi tu o spółki powiązane kapitałowo z dawnym PTKiGK Zabrze (w tym dawna Kopalnia Piasku Kuźnica Warężyńska), czy spółki napraw infrastruktury połączone w obecne Przedsiębiorstwo Napraw Infrastruktury w Warszawie. 
W 2005 r. siedziby 10 przewoźników towarowych mieściły się w woj. śląskim, co było związane z wieloletnią tradycją prowadzenia przewozów przez tamtejsze koleje przemysłowe (Taylor i Ciechański, 2005). Postanowiły one rozszerzyć swoją działalność poza obszar własnych sieci, a nawet Górnego Śląska. Znaczną część licencjonowanych przewoźników stanowiły wówczas wydziały zajmujące się transportem kolejowym, które po restrukturyzacji macierzystych zakładów zostały przekształcone w samodzielne przedsiębiorstwa transportowe (np. Lotos Kolej, Kolchem-Rokita, Coaltran). Powoływanie własnych przewoźników wynikało przede wszystkim z chęci uniezależnienia się od obcych firm transportowych, mogących narzucać niekorzystne ceny usług i/lub niedogodne warunki przewozu.

Największa liczba (15) przewoźników posiadających w 2010 r. licencje na przewozy towarowe była zarejestrowana w Warszawie - blisko połowa z nich była spółkami-córkami CTL Logistics (ryc. 2). Tak duże znaczenie tej lokalizacji należy przypisać bliskości instytucji rządowych oraz tworzeniu większości podmiotów jako nowych przedsięwzięć (typu greenfield). Ponadto, na terenie województwa mazowieckiego zlokalizowany jest jeszcze jeden przewoźnik - Orlen KolTrans. Drugim ważnym skupiskiem (12 podmiotów) przewoźników niezależnych jest Górny Śląsk - wiąże się to przede wszystkim z uwarunkowaniami historycznymi: na Śląsku już w czasach PRL-u działały podmioty prowadzące samodzielną działalność przewozową. Ponadto istniało wiele dużych zakładów przemysłowych, stanowiących źródło taboru dla rozwijających się znaczących podmiotów jak obecne CTL Logistics czy polski oddział DB Schenker. Znacząca transportochłonność śląskiego przemysłu była także z pewnością ważką przesłanką do lokowania tutaj siedzib przewoźników.

Spore skupienie (7) niezależnych przewoźników występuje na terenie województwa dolnośląskiego. Pięciu z nich zarejestrowanych jest we Wrocławiu - tu warto wymienić firmę STK zajmującą się transportem ładunków ponadgabarytowych, czy też East West Railways specjalizujące się w przewozach międzynarodowych. Dwaj pozostali przewoźnicy zlokalizowani są w Brzegu Dolnym i Lubinie (Pol-Miedź Trans). Także województwo kujawsko-pomorskie jest nieźle nasycone przewoźnikami kolejowymi. Z pięciu zarejestrowanych tu podmiotów większość wywodzi się z wydziałów transportu kolejowego przedsiębiorstw branży chemicznej (CTL Tankpol w Bydgoszczy, Transoda z Inowrocławia, Transchem z Włocławka).

Trzech przewoźników zarejestrowanych jest w województwie małopolskim nie mają oni jednak praktycznie większego znaczenia. W województwie pomorskim zarejestrowano również trzech przewoźników. Najważniejszym z nich jest firma Lotos Kolej wyspecjalizowana w obsłudze transportowej gdańskich zakładów rafineryjnych. W pozostałych województwach swoje siedziby ma najwyżej po dwóch przewoźników, a na terenie województw łódzkiego, warmińsko-mazurskiego i podlaskiego - żaden. Warto zwrócić uwagę, że część z przedstawionych na mapie podmiotów nie prowadzi z różnych przyczyn działalności przewozowej 
lub też prowadzi ją na niewielką skalę. Z drugiej strony trzeba też pamiętać, że jeden z przewoźników wąskotorowych - Stowarzyszenie Kolejowych Przewozów Lokalnych - wykonuje przewozy na krótkich odcinkach linii normalnotorowych jako podwykonawca PKP Cargo.

Polski rynek kolejowych przewozów towarowych zaczął być interesujący dla inwestorów zagranicznych ${ }^{4}$. Na początku 2003 r. Rail Polska zakupiła polską fir-

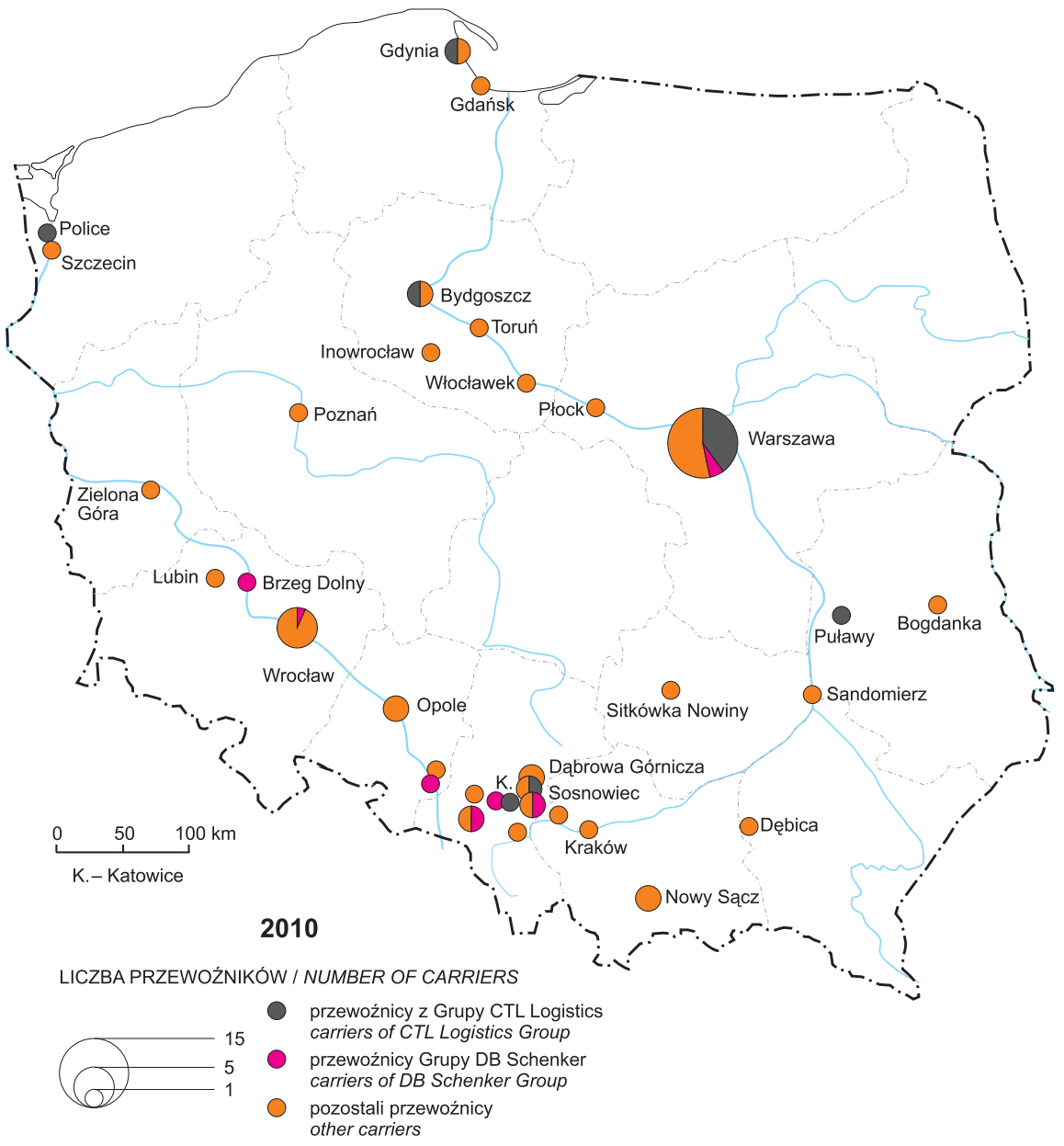

Ryc. 2. Rozmieszczenie siedzib niezależnych kolejowych przewoźników towarowych w $2010 \mathrm{r}$. Opracowanie własne.

Locations of seats of independent rail freight carriers in 2010 Authors' own work.

\footnotetext{
${ }^{4}$ Szerzej w przygotowywanej do druku pracy Z. Taylora i A. Ciechańskiego pt. Bezpośrednie inwestycje zagraniczne $w$ polskim transporcie.
} 
mę PPUH Kolex, dawny zakład transportu kolejowego firmy chemicznej Dwory w Oświęcimiu oraz firmę ZEC-Trans we Wrocławiu. Firmy te zostały następnie włączone całkowicie w struktury Rail Polska jako jej oddziały regionalne. Również największy polski właściciel wagonów-cystern DEC został zakupiony przez amerykańską firmę GATX Corporation, zajmującą się wypożyczaniem cystern i lokomotyw na rynku północnoamerykańskim. Więcej uwagi należy poświęcić dwóm innym inwestycjom zagranicznym, zwłaszcza że ich skala była ogromna.

W 2008 r. doszło do największej inwestycji obcego kapitału w polskim sektorze transportu. Brytyjski fundusz private equity Bridgepoint zakupił od Jarosława Pawluka 75\% akcji spółki CTL Logistics (o wartości szacowanej na 1,5 mld zł). CTL Logistics powstało w 1992 r. jako firma spedycyjna zlokalizowana w Warszawie i Gliwicach, później przekształcona w firmę przewozową. Jeszcze w 1992 r. została utworzona wraz z PKP spółka CTL Północ, a w dwa lata później identyczna spółka CTL Południe. Przełom nastąpił w 2000 r., kiedy to CTL zaczął inwestować w zakup innych spółek transportu kolejowego. Zakupiono wtedy firmę Tankpol wywodzącą się z zakładu transportu kolejowego bydgoskiej firmy Zachem i Chemkol będący podobnym podmiotem dla Zakładów Azotowych w Kędzierzynie-Koźlu. W 2002 r. został sfinalizowany kluczowy dla przedsiębiorstwa zakup Kopalni Piasku Maczki Bór w Sosnowcu, będącej nie tylko zakładem wydobywczym, ale przede wszystkim prężnym przedsiębiorstwem transportowym wyposażonym w 127 km w znacznym stopniu zelektryfikowanych linii kolejowych i posiadającym własny tabor kolejowy, w tym lokomotywy elektryczne kluczowe w realizacji przewozów po sieci PKP. Kontynuując rozwój w 2004 r. CTL zakupił Kolzap - dawny zakład transportu kolejowego Zakładów Azotowych w Puławach i Trans-Port bliźniaczy podmiot z portu w Gdyni. Przyłączenie firm kolejowych do grupy kapitałowej CTL-u zostało zakończone w 2005 r., kiedy to w jej skład weszła spółka Kargo zajmującą się transportem kolejowym w Zakładach Chemicznych w Policach (www.ctl.pl).

Drugim najważniejszym przewoźnikiem niezależnym po CTL Logistics jest obecnie DB Schenker. Jego historię należy jednak rozpatrywać dwutorowo jako PCC Rail i PTK Holding. Ten pierwszy podmiot został założony w Duisburgu przez Waldemara Preussnera jako Petro Carbo Chem Rohstoffhandelsgesellschaft mbH (PCC GmbH) - międzynarodowe przedsiębiorstwo działające w branży chemicznej i wielu innych. W 1998 r. z wspomnianej firmy wyodrębniło się PCC AG. W 2000 r. zostały zapoczątkowane inwestycje firmy na terenie Polski poprzez przejęcie 97,2\% udziałów w przedsiębiorstwie Sped-Kol Blachownia - dawnym zakładzie transportu kolejowego Zakładów Chemicznych Blachownia. W 2003 r. PCC dokonało jednego ze swoich największych zakupów, jeśli chodzi o transport kolejowy - kopalni piasku Szczakowa w Jaworznie, analogicznego przedsiębiorstwa jak kopalnia piasku Maczki Bór zakupiona przez CTL. W tym samym roku zostały zakupione Zakłady Chemiczne Rokita w Brzegu Dolnym wraz z podległą im spółką Kolchem Rokita. W 2004 r. PCC Rail zakupił firmę 
Coaltran, zajmującą się obsługą transportu kolejowego na rzecz Elektrociepłowni Warszawskich (www.pccrail.pl). Stopniowe zaangażowanie obecnie międzynarodowego koncernu PCC SE z Duisburga w polski transport kolejowy szacowane było łącznie na około 1 mld zł (2004). W 2007 r. przejęte zostało, wraz ze spółkami zależnymi, Przedsiębiorstwo Transportu Kolejowego i Gospodarki Kamieniem w Rybniku (do grupy PTKiGK należą m.in. Nadwiślański Zakład Transportu Kolejowego oraz Trans-Pak). Na początku 2009 r. niemiecka firma Schenker z Grupy Deutsche Bahn (DB Schenker) kupiła wszystkie akcje PCC Rail, należące do kontrolowanej przez Waldemara Preussnera PCC SE. Jedyną spółką pozostającą pod jego kontrolą została PCC Intermodal (dawna PCC Rail Containers), zajmująca się transportem ładunków w kontenerach. Również w 2009 r. DB Schenker przejęła już bezpośrednio Przedsiębiorstwo Transportu Kolejowego Holding z Zabrza.

Największą inwestycją typu greenfield w polskim sektorze kolejowych przewozów towarowych było utworzenie w 2005 r. spółki Freightliner PL należącej do brytyjskiej Grupy Freightliner. Przewoźnik ten zaczął swoją działalność w 1965 r. prowadząc przewozy kontenerowe w ramach struktur kolei brytyjskich, a rok później został sprywatyzowany. Na terenie Polski prowadzi pociągi własnym, specjalnie zakupionym taborem, którego wartość szacowana jest na ponad 30 milionów funtów. Koncentruje się na masowych przewozach towarów sypkich - węgla kamiennego i kruszyw. Ponadto obsługuje własnymi lokomotywami pociągi zestawione z wagonów stanowiących własność innych przedsiębiorstw (Śmiech, 2010).

Warto też zaznaczyć (Raport..., 2009), że stale wzrasta liczba przewoźników towarowych biorących udział w wymianie międzynarodowej, a korzystających z sieci PKP Polskich Linii Kolejowych. W 2005 r. było ich zaledwie 8, rok później 13, w 2007 r. 16, a w 2008 już 21.

\section{Praca przewozowa i przewozy ładunków kolejami}

Rozpatrując ruch towarowy obserwuje się znaczącą przewagę spółki Grupy PKP (Cargo + LHS; por. ryc. 3), jednak ekspansja przewoźników niezależnych przybiera na sile. Szczególnie zaznaczył się moment wejścia w życie nowej Ustawy o transporcie kolejowym w 2003 r., od którego to udział przewoźników niezależnych zaczął stopniowo, a potem gwałtownie przyrastać osiągając w 2009 r. poziom ponad 30\%. Na taki obraz struktury pracy przewozowej wpływa zapewne technologia przewozów. Przewoźnicy niezależni prowadzą wyłącznie zwarte składy, stanowiące przesyłki całopociągowe. Z kolei PKP Cargo, oprócz przesyłek całopociągowych, transportuje również przesyłki drobnicowe, wymagające utrzymywania większej liczby pociągów na trasach łączących ze sobą stacje rozrządowe, stacje manewrowe z rozrządowymi, czy wreszcie pociągi zdawcze, które ze stacji manewrowych dostarczają przesyłki do stacji docelowych i na bocznice. 
Pod względem realizowanej pracy przewozowej liderem wśród przewoźników prywatnych jest od początku CTL. Dopiero w kolejnych latach wzrastało znaczenie PCC Rail Szczakowa oraz PTKiGK Zabrze. Jeszcze później znaczącym pod względem wykonywanej pracy przewozowej przewoźnikiem stał się Lotos Kolej.

2003

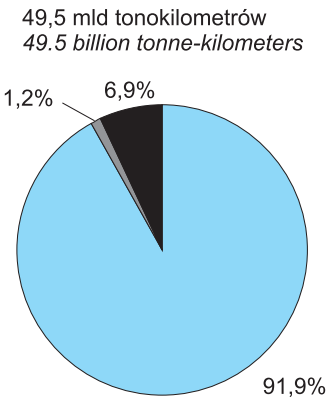

2007

40,6 mld tonokilometrów 40.6 billion tonne-kilometers

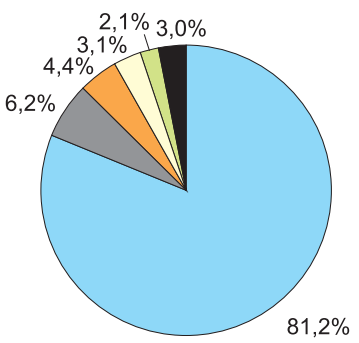

Grupa PKP (Cargo+LHS)

CTL Rail

PCC Rail Szczakowa / DB Schenker Rail
2005

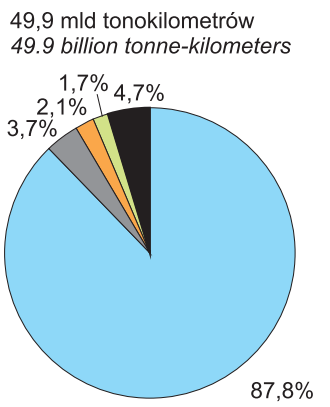

2009

42,9 mld tonokilometrów 42.9 billion tonne-kilometers

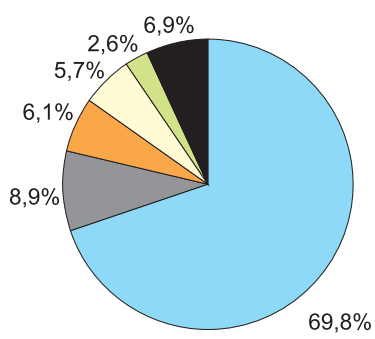

$69,8 \%$

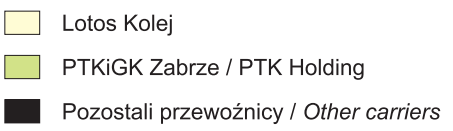

Ryc. 3. Praca przewozowa w ruchu towarowym

Opracowanie własne na podstawie: Wyniki przewozów w 2005 r. (2006); Towarowe... (2009); Malinowski (2010).

Transport effort in freight traffic

Authors' own work based on: Wyniki przewozów w 2005 r. (2006); Towarowe... (2009);

Malinowski (2010).

Inny obraz zderegulowanego rynku uzyskamy biorąc pod uwagę wielkość przewozów w tonach (ryc. 4). Do roku 2003 przewoźnicy spoza PKP praktycznie nie byli ujmowani w statystyce publicznej - trudno więc dokonywać jakichkolwiek porównań. Także statystyka publikowana po 2003 r. wzbudza wiele 
2003

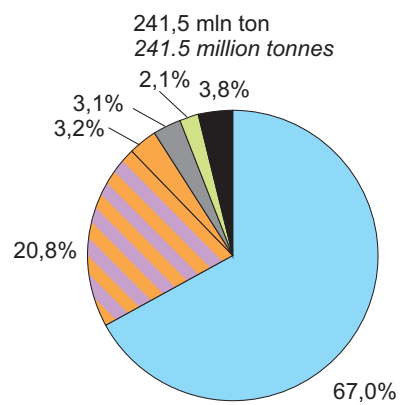

2007

289,0 mln ton 289.0 million tonnes
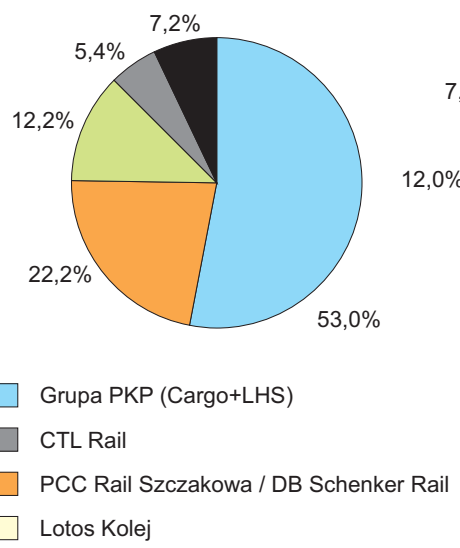

Grupa PKP (Cargo+LHS)

CTL Rail

PCC Rail Szczakowa / DB Schenker Rail

Lotos Kolej

2005

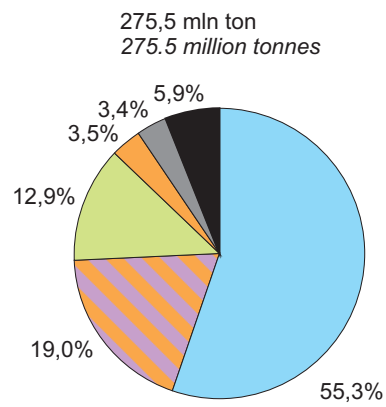

2009

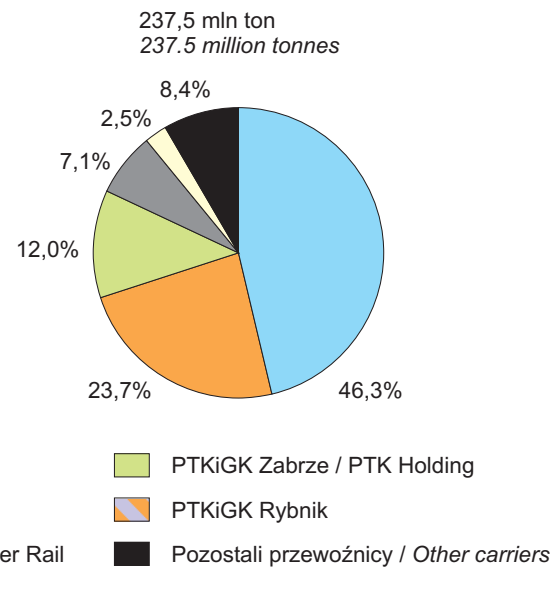

Ryc. 4. Przewozy w ruchu towarowym

Opracowanie własne na podstawie: Wyniki przewozów w 2005 r. (2006); Towarowe... (2009); Malinowski (2010).

Carriage in freight traffic

Authors' own work based on: Wyniki przewozów w 2005 r. (2006); Towarowe... (2009); Malinowski (2010).

zastrzeżeń ze względu na znaczące różnice w metodologii zbierania danych (w niektórych latach do przewożonej masy wliczano manewry, powodując często podwójne liczenie tej samej tony ładunku). Właśnie szczegóły natury statystycznej powodowały, że w udział podmiotów z Grupy PKP (PKP Cargo i PKP LHS) już w 2003 r. był na poziomie 2/3 przewożonych ładunków. Z tego samego powodu w latach 2003 i 2005 liderem wśród przewoźników prywatnych stał się PTKiGK Rybnik wykonujący wówczas większość swoich przewozów po sieci 
własnej i Jastrzębskiej Spółki Kolejowej, między kopalniami węgla kamiennego a punktami zdawczo-odbiorczymi na sieci PKP PLK (warto zwrócić uwagę, że udział tego operatora w pracy przewozowej jest znacznie mniejszy). Drugim pod względem przewiezionej masy przewoźnikiem w obserwowanych przedziałach czasowych była bliźniacza do rybnickiego przedsiębiorstwa spółka PTKiGK Zabrze. W 2007 r. na pozycję lidera wysunęła się firma PCC Rail Szczakowa stało się tak ze względu na przypisanie jej wyników transportowych całego holdingu PCC Rail - dlatego nieuwzględniany był już na przykład PTKiGK Rybnik. W 2009 r., po wykupieniu holdingu PCC Rail przez niemieckiego państwowego przewoźnika kolejowego DB Schenker firma ta stała się niekwestionowanym liderem na rynku. Warto zwrócić uwagę, że po przejęciu przez DB Schenker w 2009 r. PTK Holding Zabrze, rola tego przewoźnika wzrosła jeszcze bardziej. Co interesujące, kreowany wielokrotnie przez branżowe media na lidera wśród przewoźników prywatnych CTL (pod względem masy wykonywanych przewozów) zajmował najwyżej trzecią pozycję. Po koniec dziesięciolecia coraz większe znaczenie zaczął zyskiwać inny przewoźnik - Lotos Kolej. Pozostali przewoźnicy mieli w 2009 r. mniej niż 2,5\% udział w rynku każdy (Malinowski, 2010). Do ważniejszych z nich należy zaliczyć Pol-Miedź Trans z Lubina (1,7\%), Kopalnię Piasku Kotlarnia (1,6\%), Orlen KolTrans (1,3\%), Nadwiślański Zakład Transportu Kolejowego (1,0\%) i Rail Polska (1\%). Niewiele poniżej 1\% ładunków przewozi brytyjski Freightliner. Inni przewoźnicy jak Transoda, Kolprem, czy Zakład Inżynierii Kolejowej z Sandomierza przewożą znacznie mniej niż 1\% ładunków każdy.

$\mathrm{Na}$ zakończenie omówienia sytuacji na rynku przewozów kolejowych w 2009 r. warto zwrócić uwagę na średnie odległości przewożonych ładunków. Wśród przewoźników prywatnych średnio na największe odległości swoje pociągi prowadzi firma Lotos Kolej (404,9 km). Jest to więcej niż w przypadku PKP Cargo (269,6 km), a nawet PKP LHS (317,6 km). Także drugi w kolejności pod tym względem przewoźnik - Orlen KolTrans odnotowuje większe odległości (319,5 km) niż w przypadku spółek Grupy PKP. Należy tu zwrócić uwagę na jedną prawidłowość - obaj przewoźnicy są wyspecjalizowani w przewozach paliw płynnych. Warto też spojrzeć na wyniki największych przewoźników niezależnych - DB Schenker Rail przewoził średnio na odległość 46,8 km, a znajdujący się obecnie w tej samej grupie PTK Holding z Zabrza - 39,7 km. Świadczy to o nadal bardzo silnym powiązaniu wspomnianych przewoźników z rynkiem, z którego się wywodzą. Jednak z drugiej strony, CTL Rail, o dość podobnym rodowodzie osiągał porównywalne z PKP Cargo 226,3 km, a powstały praktycznie od podstaw Freightliner nawet 290,9 km. Jednocześnie na najmniejsze odległości przewoziły Nadwiślański Zakład Transportu Kolejowego i Kopalnia Piasku Kotlarnia (odpowiednio: 26,1 i 32,8 km). 
Mimo dużych ułatwień w ostatnich latach, sytuacja przewoźników wywodzących się spoza Grupy PKP SA ciągle odbiega od ich oczekiwań. Przewoźnicy niezależni mieli dość długo trudności w korzystaniu z infrastruktury innych spółek Grupy PKP SA, ze stacji rozrządowych, torów łączących z terminalami portowymi, kontenerowymi i przeładunkowymi PKP Cargo. Powoduje to brak możliwości poszerzenia oferty transportowej przewoźników niezależnych o przewozy pojedynczych wagonów i grup wagonów. Utrudnieniem są także jedne z najwyższych w Europie stawki za dostęp do infrastruktury, a także monopolistyczna pozycja PKP Cargo, przejawiająca się w narzucaniu kontrahentom wieloletnich umów na wyłączność przewozów, utrudnianiu zakupu zbędnego taboru i w naprawach (Nietz, 2005). Dopiero na 2010 r. przewidywane jest ostateczne przekazanie punktów ładunkowych z PKP Cargo do PKP Polskich Linii Kolejowych.

\section{Piśmiennictwo}

Ciechański A., 2002, Koleje przemystowe na Górnym Ślqsku w okresie transformacji gospodarczo-ustrojowej, Wydział Geografii i Studiów Regionalnych UW, Warszawa, maszynopis.

-, 2003, Koleje przemystowe na Górnym Ślasku jako nowe zarzady kolejowe, Prace Komisji Geografii Komunikacji PTG, 9, Warszawa-Rzeszów, s. 211-250.

Dyr T., 2008, Szanse i zagrożenia dla rozwoju rynku kolejowych przewozów regionalnych, Technika Transportu Szynowego, 11, s. 51-57.

Kierunki rozwoju konkurencji i ochrony konsumentów na rynkach przewozów kolejowych w Polsce, 2010, Urząd Ochrony Konkurencji i Konsumentów, Warszawa.

Koncesje i licencje na polskim rynku ustug kolejowych, 2003, Rynek Kolejowy, 3, 7-8, s. 4-17.

Malinowski Ł., 2010, Przewozy towarowe w 2009 r., Rynek Kolejowy, 3, s. 54-56.

Nietz F., 2005, Batalia o wolne tory, Polska Gazeta Transportowa, 13, 1, s. 2.

Ocena funkcjonowania transportu kolejowego, 2004, Transport i Komunikacja, 1, 4-6, s. 28-33.

Portret Grupy PKP 2003, 2003, PKP SA, Warszawa.

Raport 2001, 2002, PKP PLK, Warszawa.

Raport 2008, 2009, PKP PLK, Warszawa.

Regulamin przydzielania $i$ korzystania z tras pociagów na infrastrukturze kolejowej zarzadzanej przez JSW S.A. - KWK „Budryk” w ramach rozktadu jazdy 2009/2010, 2009, http://www.jsw.pl/documents/zaklady/budryk/uik/regulamin-2009.pdf (15.10.2010).

Regulamin przydzielania tras pociagów $i$ korzystania z przydzielonych tras przez licencjonowanych przewoźników kolejowych w ramach rozkładu jazdy pociagów na rok 2009/2010, 2009, http://www.infrasilesia.pl/pdf/Regulamin_2009-2010_IS_ wer_2_0.pdf (15.10.2010).

Regulamin przyznawania tras pociagów $i$ korzystania z przydzielonych tras przez licencjonowanych przewoźników kolejowych na liniach kolejowych zarzadcy CTL Maczki- 
Bór sp. z o.o. na czas obowiazywania stużbowego rozkładu jazdy 2009/2010, 2009, http://www.ctl.pl/dl/1267714000_Regulamin_2009_2010.pdf (15.10.2010).

Regulamin przydzielania tras pociagów $\bar{i}$ korzystania z przydzielonych tras pociagów przez licencjonowanych przewoźników kolejowych w okresie obowiazywania rozkładu jazdy pociagów ważny na 2009/2010 rok, 2009, www.kotlarnia.com.pl (15.10.2010). Regulamin przydzielania $i$ korzystania z tras na udostepnionych liniach kolejowych w ramach RJP 2009/2010, www.jsk.pl/oferta/udostepnienie.php (15.10.2010).

Rozporzadzenie Rady Ministrów z dnia 27 listopada 2008 r. w sprawie określenia liczby udziałów samorząów województw w kapitale zakładowym PKP Przewozy Regionalne spótka z ograniczona odpowiedzialnościa (z uzasadnieniem), 2008, Dziennik Ustaw, 218, poz. 1393.

Śmiech W., 2010, Freighliner - brytyjski gigant w polskim wydaniu, Rynek Kolejowy, 10, s. $50-51$.

Taylor Z., 2002, Zmiany w polskiej polityce transportowej ostatnich lat, [w:] J. Wendt (red.), Wybrane zagadnienia geografii transportu, Uniwersytet Szczeciński, Szczecin, s. $72-83$.

-, 2007, Rozwój i regres sieci kolejowej w Polsce, Monografie, IGiPZ PAN, 7, Warszawa.

Taylor Z., Ciechański A., 2005, Deregulacja w polskim transporcie kolejowym, Przegląd Geograficzny, 77, 2, s.139-169.

Towarowe dane przewozowe za 2008 r. - szczegóty, 2009, www.rynek-kolejowy.pl (7.10.2010).

Transport-wyniki działalności 2008, 2009, GUS, Warszawa.

Ustawa z dnia 27 czerwca 1997 r. o transporcie kolejowym, 1997, Dziennik Ustaw RP, 96, poz. 591.

Ustawa z dnia 8 września 2000 r. o komercjalizacji, restrukturyzacji i prywatyzacji przedsiębiorstwa państwowego Polskie Koleje Państwowe, 2000, Dziennik Ustaw RP, 84, poz. 948.

Ustawa z dnia 6 września 2001 r. o transporcie drogowym, 2001, Dziennik Ustaw RP, 125, poz. 1371.

Ustawa z dnia 28 marca 2003 r. o transporcie kolejowym, 2003a, Dziennik Ustaw RP, 86, poz. 789.

Ustawa z dnia 13 listopada 2003 r. o dochodach jednostek samorzaddu terytorialnego, 2003b, Dziennik Ustaw RP, 203, poz. 1966.

Ustawa o z dnia 25 kwietnia 2008 r., o zmianie ustawy o komercjalizacji, restrukturyzacji i prywatyzacji przedsiębiorstwa państwowego Polskie Koleje Państwowe, 2008, Dziennik Ustaw RP, 97, poz. 624.

Ustawa o publicznym transporcie zbiorowym (projekt), 2010, www.bip.mi.gov.pl (05.10.2010).

www.ctl.pl - oficjalna strona internetowa CTL Logistics (15.10.2010).

www.koltarnia.com.pl - strona internetowa Kopalni Piasku „Kotlarnia” SA (15.12.2004).

www.kpszczakowa.pl - strona internetowa PCC „Rail Szczakowa” SA (15.12.2004).

www.lhs.pl - nieoficjalna strona internetowa LHS (15.12.2004).

www.pccrail.pl - oficjalna strona internetowa PCC Rail (18.01.2010).

www.plk-sa.pl - oficjalna strona internetowa PKP PLK SA (15.12.2004).

www.utk.gov.pl - oficjalna strona Urzędu Transportu Kolejowego (10.01.2005, 15.09.2010).

Wykaz linii, tacznic i torów tączacych D29, 1999, Dyrekcja Generalna PKP, Warszawa.

Wyniki przewozów w 2004 r., 2005, Rynek Kolejowy, 3, s. 22-24.

Wyniki przewozów w 2005 r., 2006, Rynek Kolejowy, 6, s. 22-25.

[Wpłynęło: październik 2010 r.] 


\section{ZBIGNIEW TAYLOR, ARIEL CIECHAŃSKI}

\section{RECENT ORGANIZATIONAL AND OWNERSHIP TRANSFORMATION IN RAIL TRANSPORT COMPANIES IN POLAND - PART I}

This paper described an attempt at the reconstruction of organizational and ownership transformations affecting rail transport companies in Poland after the year 2000. It consists of two parts, the first (published in this issue of Przeglad Geograficzny) addressing organizational changes and the establishment of new operators in freight traffic on standard- and broad-gauge railways. In the second part (to be published in Przeglad Geograficzny of 2011, 83, 2), it is passenger traffic on standard-gauge railways and carriers on narrow-gauge railways that will be analysed.

Although relevant areas of the legal system have not in general been changed since 2003, the organizational-ownership changes in rail transport up to the mid-2000's were at most very modest, mainly embracing independent (i.e. non-PKP Group) freight rail carriers on standard-gauge railways, with other carriers being affected to a minimal degree. However, transformation processes accelerated in the second half of the 2000's, and it is the processes involved in this case that are the subject of this article, along with their implications.

The year 2000 was the last one for the Polish State Railways (PKP) company, a new Act of 2000 providing for the transformation of the formerly state-owned enterprise into a single-personality Treasury company. The following year saw the split into 24 different companies creating a capital group along with the original parent. The more important of these companies administer rail infrastructure, separated infrastructure and traffic on it, and traffic only. The restructuring of PKP also entailed a problematic split-up of rolling-stock.

In passenger traffic, important changes included regionalization, as well as a later injection of self-governing powers. The two processes have together denoted the division of the PKP Przewozy Regionalne national company into 16 companies at the level of the Polish voivodships (province-regions), with an attendant transfer of assets, staff, and debts to the regional authorities in the voivodships (Table 1). This is a very controversial reform, since the national monopoly has been transformed into 16 regional monopolies, with all the inevitable detrimental effects that entails.

Interesting processes are taking place in the freight traffic company called PKP Cargo. On the one hand, various rolling-stock works and freight carriage units of the company have been consolidated into 16 companies located throughout Poland. On the other hand, a simultaneous process of the outsourcing of repair activities has been taking place.

Until 2002, railway lines administred by the PKP PLK company were practically inaccessible to independent companies, i.e. companies outside the PKP Group. A majority of operators were supplying freight traffic on the rail network of the former Silesian industrial railways. The carriers focused on providing freight for power stations, supplying them with coal on the rail network of sand-transporting companies.

As of August 2010, 88 licences for freight-traffic carriers have been issued (Fig. 1, Table 4). The peak intensity of licensing took place in the years 2003-2005, with an average of 14-25 licenses issued per annum. 
In 2010, the most seats of licensed independent freight carriers were registered in Warsaw (15), half of these being daughter-companies of CTL Logistics (Fig. 2). Such a concentration reflects proximity to government agencies, and the establishment of a majority of the firms as greenfield investments. The second cluster of independent freight carriers is in Upper Silesia - a situation that has its historical justifications. The presence of large industrial plants is a further reason for the locations of carriers belonging to CTL Logistics or the Polish branch of DB Schenker. Quite a large cluster of independent carriers is present in Lower Silesia, five being located in the city of Wrocław and two others at the large industrial plants in Brzeg Dolny and Lubin. Likewise, in Kujawsko-Pomorskie voivodship, five carriers are connected mainly with large chemical industry plants.

The Polish rail freight market has started to be of greater interest to foreign investors. At the beginning of 2003, Rail Polska (a subsidiary of Rail World) bought two Polish firms, i.e. PPHU Kolex - a former rail transport unit of the Dwory chemical plant near Oświęcim, and ZEC-Trans located in the city of Wrocław. The two firms were next incorporated into Rail Polska as regional branches. In addition, DEC, the largest Polish owner of tank-wagons, has been purchased by America's GATX Corporation. However, the largest ventures were two other brownfield foreign investments.

2008 brought the largest foreign direct investment in the Polish transport sector, as the British private equity fund Bridgepoint purchased 75\% of the shares in CTL Logistics from Jarosław Pawluk (the estimated value of the transaction being 1.5 billion zloties). The Group comprised some 20 companies, mainly in freight rail transport throughout Poland and in neighbouring countries. The second largest FDI into Polish transport in turn involved DB Schenker, which took over an absolute majority stake in Waldemar Preussner's empire, namely PCC Rail as part of the international multibranch concern PCC of Duisburg. The value of that transaction was estimated at 1 billion zloties.

The largest greenfield investment in freight rail traffic is on a much smaller scale, however. In 2005, Freightliner PL belonging to the British Freightliner Group invested in rolling-stock for the transport of mass cargo like coal and aggregates.

Where rail freight traffic is concerned, PKP Cargo maintains its enormous advantage over other companies, though the competition posed by independent carriers is more and more effective. The share taken by the latter now exceeds 30\% (expressed in tonne-km, see Fig. 3) - this boost reflecting traffic technology. The independent carriers transport their goods as whole trains only, which means they are not interested in shipping general cargo for multipurpose destinations. Among independent carriers the top positions are held by CTL, followed by PCC Rail Szczakowa, PTKiGK Zabrze, and Lotos Kolej.

A slightly different picture is observed when carriage in tonnes is taken into account (Fig. 4). Here, the leader among the independent carriers is PTKiGK Rybnik, followed by PTKiGK Zabrze and PCC Rail Szczakowa, though the hierarchy changed in 2009 when DB Schenker purchased PCC Rail and took the number one position. However, it should furthermore be recalled how the statistical methodology has changed several times, ensuring at least a partial non-comparability of results. 
http://rcin.org.pl 